\title{
Mathematics Literacy as a Foundation for Technological Development in Nigeria
}

\author{
${ }^{1}$ Mr. Adeyemi O.B, ${ }^{2}$ Adaramola, M.O (PhD) \\ ${ }^{I}$ Department of Curriculum Studies \& Educational Technology \\ University of Port Harcourt, Rivers State, Nigeria. \\ ${ }^{2}$ Federal Inspectorate service, Federal Ministry of Education, Port Harcourt.
}

\begin{abstract}
The role of mathematics literacy is critical to the realization of Universal Basic Education as it contained in the Millennium Development Goals (MDGs). Therefore, mathematics literacy must be improved with relevant teaching materials, mathematical laboratory and e-library, to meet the expected programme of Universal Basic Education. If mathematics literacy is well-developed, improved and adequately managed, it can lead to acquisition of mathematics skills which can lead to achievement of Universal Basic Education. Based on this premise, this paper explores the relevance of mathematics literacy as a complementary tool to the achievement of technical education especially at the Universal Basic Education level in Nigeria. It has also suggested ways through which Technological development would be attained in Nigerian schools. The paper recommends that mathematics literacy should be improved through provision of mathematical laboratory, elibrary and electronic board, also funds should be made available to purchase computers, as well as provide inservice training, workshop and conferences for teachers on a rotational basis to fast track Technological Developments in schools in Nigeria.
\end{abstract}

Keywords: Mathematics literacy, Technological Development

\section{Introduction}

Mathematics literacy is a subset of mathematics and also the bedrock of sciences and technology. To improve the technological development in Nigeria, the country needs to develop her mathematics literacy skills. Before now the Federal Government of Nigeria has said that education is an instrument par excellence for effecting national development (FRN, 2004). In other to achieve technological development the human capital must be developed through mathematics literacy. The level of development of a nation depends heavily on the education sector. Literacy is also a yardstick for development. Mathematics is one of the core subjects taught in schools, yet the level of mathematics literacy of Nigerians is questionable. Ability to transfer skills learnt in mathematics to other school subjects is necessary to achieve technological development. Mathematics help students develop logical reasoning, creativity, problem solving skills to mention but few. Adaramola and Onwioduokit (2010).

Numeracy involves being able to identify, understand, and use numerical arguments in various everyday contexts. Numeracy requires both knowing elementary mathematics and understanding it well (Hughes, 2004). Adopting this definition, those who know arithmetic only as algorithms to be memorized are clearly not numerate. Hughes further pointed out that numeracy insists on understanding. This understanding must be flexible enough to enable its owner apply numerical ideas in new contexts as well as in familiar contexts. Numeracy is not about how much elementary mathematics a person knows but about how well it can be used. Hence it is simply concerned with ability to count, using numbers, reading and identifying numerals, reading charts and ability to record some information in numerical way. Numeracy literacy involves understanding some elementary mathematics and possesses the ability to use it well. Mogens (2001) was of the view that numeracy has different names such as quantitative literacy, numeracy, mathematical literacy, and mathematical competencies. O'Donoghue (2002) said in practice the term may signify any one of a number of things including, basic computational arithmetic, essential mathematics, social mathematics, survival skills for everyday life, quantitative literacy, mathematical literacy and an aspect of mathematical power. These descriptions span a spectrum of personal abilities from basic skills to high-level cognitive abilities such as problem solving and communication. Onwioduokit and Adaramola (2011) opined that Mathematics literacy is far more tasking than numeracy literacy. A mathematically literate person, grasps a large number of mathematical concepts and can use them in mathematical contexts, but may or may not be able to apply them in a wide range of everyday contexts. A quantitatively literate person may know many fewer mathematical concepts, but can apply them widely (Hughes, 2004). Mathematics is more permanent than almost any other human cultural activity in school. Mathematics has its roots in methods often dating back to several thousand years. Mathematics is very different from (basic) "numeracy" or "mathematical literacy". "Numeracy" and "mathematical literacy" are best seen as two in one, because numeracy is a subset of mathematics literacy; both 
of them are subsets of mathematics. The role of mathematical literacy in the shaping and maintenance of democracy has been to equip citizens with the prerequisites needed to involve themselves in issues of immediate societal significance Mogens, (2001). Numeracy literacy only requires willingness on the part of an individual to engage effectively with quantitative information in simple settings. Numeracy is not about how much mathematics a person knows but about how well it can be practically used. Mathematics literacy cannot be achieved without thorough knowledge of school mathematics. Hence the country needs a very strong mathematical literacy programme to achieve basic technology education which will lead to attaining technological development in Nigeria.

\section{Statement of the Problem}

Basic technology is a compulsory foundation subject taught in the junior secondary schools in Nigeria. It is obvious from above that the knowledge learnt in mathematics is relevant for the study of basic technology. Poor performance in Basic technology has created hindrances for some students from studying technical subjects in the senior secondary school level and eventually studying Engineering in the University. Adaramola, (2011), Uka and Iji (2013), Obomanu and Adaramola (2011) all believed and established by research that there is poor academic performance in Mathematics. It is against this background that the researchers got involved in this study. This research is set to investigate the effect of mathematics literacy on basic technology in Nigeria.

\section{Purpose of the Study}

The purpose of the study is to investigate the effect of mathematics literacy on technological development in Nigeria, specifically the objectives of the study are:

1 To find out the effect of mathematics literacy on basic technology;

2 To determine the performance of boys and girls taught basic technology with mathematical literacy concepts.

\section{Research Questions}

1. What differences exist between the performances of students taught basic technology with mathematics literacy and those not?

2. Is there any difference in the performance of boys and girls taught basic technology with mathematical literacy concepts?.

\section{Research Hypotheses}

$\mathrm{Ho}_{1}$ There is no significant difference between the performance of those taught basic technology with mathematics literacy and those not.

$\mathrm{Ho}_{2}$ There is no significant difference between the performance of boys and girls taught basic technology with mathematics literacy.

\section{Methodology}

This is a quasi-experimental study with a pretest- posttest control group design, is considered most appropriate because both the experimental and control groups are subjects to randomization. Two schools were randomly selected for this study, in each of the schools; there is the experimental group and the control group. The design was chosen because it is very economical. It also allowed the use of intact classes and easily controls the reactive effect of experimentation. The experimental group was taught basic technology using mathematical literacy concepts while the control group received only basic technology teaching. Both groups were subjected to the same achievement test.

\section{Population/Sample}

The population of this study consisted of all the junior secondary schools two (JSS2).students in the government approved secondary schools in Port Harcourt metropolis. Approximately 2,654 students constituted the population of this study (Rivers state ministry of education 2013).

The schools are public schools; randomly selected by Stratified Random Sampling using Table of Random Numbers. See Table 1.

Table 1: Sample Size of Study

\begin{tabular}{|l|l|l|l|}
\hline & School 1 & School 2 & \\
\hline Experimental Group & $50(25$ Boys, 25Girls $)$ & $50(25$ Boys, 25Girls $)$ & 100 \\
\hline Control Group & $50(25$ Boys, 25Girls $)$ & $50(25$ Boys, 25Girls $)$ & 100 \\
\hline Total & 100 & 100 & 200 \\
\hline
\end{tabular}




\section{Research Instrument}

The instrument used for this study was Drawing Practice Achievement Test (DPAT) consisting of 30 multiple choice objective question in Drawing instrument and materials, Board practice, freehand sketching, Scale and scale drawing, positioning and drawing the title block, freehand writing legible letters, numerals, Using the tee square for drawing, using set squares for Constructing Lines, Angles, Circles, Triangles and Quadrilaterals.

\section{Reliability and Validity}

The test items were selected from National Examinations Council (NECO) past Questions. This ensures its Validity, while a test retest reliability and Pearson product moment was used to estimate the reliability coefficient and found it to be 0.83 .

\section{Data Collection}

The students in both groups are taught for a period of 5 days each. For the experimental group, mathematical literacy theme was used in teaching basic technology which includes Geometry, Mensuration, Drawing Practice and Building. For the Control group, Basic Technology was taught without using Mathematical theme. Then, the multiple choices objectives of 30 questions were administered to both groups as post - test. The scripts were collected and marked. The teachers were used as research assistants and they taught these students in their different schools at normal school time to prevent experimental errors.

\section{Data Analysis}

Mean and Standard Deviation were used to answer the research Questions while Analysis of Co-Variance (ANCOVA) calculated at $\alpha=0.05$ level of significance was used to test the hypotheses.

\section{Answers to Research Questions}

Table 2: Gain scores of Mathematics Performance of students based on the two methods

\begin{tabular}{|l|l|l|l|l|l|l|l|}
\hline & & $\mathrm{N}$ & $\begin{array}{l}\text { Pre test } \\
\text { Mean }\end{array}$ & Post test Mean & Mean Gain & \% Gain & $\begin{array}{l}\text { Std. } \\
\text { Deviation }\end{array}$ \\
\hline Traditional method & Boys & 50 & 9.08 & 9.60 & 0.52 & 5.42 & 3.77338 \\
(Control) & Girls & 50 & 9.38 & 14.24 & 4.86 & 34.13 & 1.02140 \\
\hline $\begin{array}{l}\text { Mathematics Literacy } \\
\text { (Experimental) }\end{array}$ & Boys & 50 & 10.14 & 20.22 & 10.08 & 49.90 & 3.77581 \\
\hline Total & Girls & 50 & 10.54 & 20.86 & 10.32 & 49.50 & 3.39874 \\
\hline
\end{tabular}

Research Questions one: What differences exist between the performances of students taught basic technology with mathematics literacy and those not?

Table 2 shows that students taught Using mathematics literacy method had the higher gains (49.9\% and 49.5\%) than those taught using the traditional method (. 5.4\% and $34.13 \%)$

Research Questions two: Is there any difference in the performance of boys and girls taught basic technology with mathematical literacy concepts?.

Table 2 shows that boys taught Using mathematics literacy method had the higher gains (49.9\%) than girls $(49.5 \%)$.

\section{Research Hypotheses}

$\mathrm{Ho}_{1}$ There is no significant difference between the performance of those taught basic technology with mathematics literacy and those not.

Table 3:- Analysis of Covariance, showing the effect of teaching methods on students' performance for Experimental and Control Groups.

\begin{tabular}{|l|l|l|l|l|l|}
\hline Source & $\begin{array}{l}\text { Type III Sum of } \\
\text { Squares }\end{array}$ & df & Mean Square & F & Sig. \\
\hline Corrected Model & $44.446(a)$ & 1 & 44.446 & 1.375 & NS \\
Method & 5703.780 & 1 & 5703.780 & 176.334 & S \\
Pretest & 44.446 & 1 & 44.446 & 1.375 & NS \\
Error & 6372.267 & 197 & 32.347 & & \\
Total & 58074.000 & 199 & & & \\
Corrected Total & 6616.714 & 198 & & & \\
\hline
\end{tabular}

a R Squared $=.037$ (Adjusted R Squared $=.032$ ) 
Table 3 shows that there is a significant difference between the teaching methods in students performance since $\left(\mathrm{F}_{1,197}=176.33, \mathrm{p}<0.05\right.$ Critical value $\left.=3.89\right)$.

$\mathrm{Ho}_{2}$ There is no significant difference between the performance of boys and girls taught basic technology with mathematics literacy.

Table 4:- Analysis of Covariance, showing the effect of teaching methods on Gender for Experimental Group.

\begin{tabular}{|l|l|l|l|l|l|}
\hline Source & $\begin{array}{l}\text { Type III Sum of } \\
\text { Squares }\end{array}$ & df & Mean Square & F & Sig. \\
\hline Corrected Model & $3.493(\mathrm{a})$ & 1 & 3.493 & .83 & NS \\
Gender & 154.294 & 1 & 154.294 & 36.88 & S \\
Pre test & 3.493 & 1 & 3.493 & .83 & NS \\
Error & 409.947 & 98 & 4.183 & & \\
Total & 3164.000 & 100 & & & \\
Corrected Total & 413.440 & 99 & & & \\
\hline
\end{tabular}

a R Squared $=.002$ (Adjusted R Squared $=-.008$ )

Table 4 shows that there is a significant difference between the performance of boys and girls taught using mathematical literacy since $\left(\mathrm{F}_{1,98}=36.88, \mathrm{p}<0.05\right.$ Critical value $\left.=3.92\right)$.

\section{Conclusion and Recommendations}

There are benefits derived from the use of mathematical literacy method. With mathematical literacy method, students no longer receive knowledge but partake in making it. There should be a shift from traditional way of teaching and teachers should search for different types of methods which will facilitate different topics in mathematics. Gender is also found to be significant to the favour of boys. This agrees with the opinion of some researchers such as Odili and Maduabum (2007), Alio and Habor-Peters(2000), Ojo(2004) and Onabanjo(2000) who said that boys are better than girls in mathematics achievements.

This study can be carried out to other places for cross validation. Attempts should be made to introduce other learning environments which were absent in this study.

\section{Reference}

[1]. Adaramola, M.O. (2011) Bridging the gender gap in mathematics performance through mathematical games: Implication for basic education in Nigeria. The Proceedings of Mathematical Association of Nigeria Conference in September, 2011. 64-70.

[2]. Adaramola M.O. and Onwioduokit. F.A.(2010) Relative effectiveness of two problem solving models on students' performance in further mathematics in secondary schools in Rivers state. Nigerian Journal of Science and science Education. 8 (2) $24-45$

[3]. Adetunde, I.A.(2009):Improving the teaching and learning of mathematics in second circle institutions in Ghana: ,Science Journal, 2(5).Retrieved on May 8, 2013, from http://www.sciencepub.net/newyork.

[4]. Ale, S. (2012) Underscoring the important of science and technology. Retrieved on May 8, 2013, from http://www.punching.com

[5]. Alio, R. C and Habor-Peters, V.F (2000) Effect of polya's problem solving technique on secondary school students'.Achievement in mathematics. ABACUS the Journal of mathematical association of Nigeria (MAN) 25(1) 20-25.

[6]. D'Ambrosio, U. (2009):The role of mathematics in building a democratic society. Retrieved on March 17, 2013, from www.maa.org/g/pg235-238pdf

[7]. Federal Republic of Nigeria (2004): National policy on education. Lagos: NERDC Press.

[8]. Federal Ministry of education (2007) 9-Y ear basic education curriculum: basic technology for Jss 1-3. Abuja: NERDC press.

[9]. Federal Ministry of Education (2007) 9-Year basic education curriculum: mathematics for Jss 1-3. Abuja: NERDC press.

[10]. Hughes, D.H, (2004) How is numeracy different from elementary mathematics? Retrieved on March 17, 2013, from math.arizona.edu/-dhh/NOVA/BIRS-numeracy.do.c. University of Arizona/Harvard University.

[11]. Jerusha, P. D. (2010): Fostering girls-child participation in science, technology and mathematics education for sustainable development in Nigeria. Science, technology and environmental education. Retrieved on May 8, 2013, from njostee.net/mydocs (13) 17.

[12]. Kaiser, G. and Willander, T (2005): Development of mathematics literacy: results of an empirical study. Retrieved on April 26, 2013, from www.epb.uni.hamburg.de.pdf.

[13]. Mogens, N. (2001): Quantitative literacy and mathematical competencies. Retrieved on May 8, 2013, from www.maa.org/q1/pgs215_220.pdf

[14]. Obomanu, B.J. and Adaramola, M.O.(2011) Factors related to under achievement in science technology and mathematics education (STME) in Nigerian secondary schools. World Journal of Education. An online journal of education. http://www.sciedu.ca.ng 1 (1) 102-109

[15]. Odili G.O. and Maduabum,M.A.(2007) trend in gender performance in futher mathematics in Nigeria: a survey ABACUS: the journal of mathematics association of Nigeria. 32(1)115-123

[16]. Onabanjo, J.O (2000) Peer tutoring assisted instruction; parents supportiveness and students' locus of control as determinant of learning outcomes in senior secondary school mathematics. Unpublished Ph.D thesis. Unibadan.

[17]. Ojo, J. O (2004) Relative effectiveness of self regulatory and cooperative learning strategies on learning outcomes in secondary mathematics in Ibadan North, Nigeria. Unpublished Ph.D thesis. Unibadan

[18]. Onwioduokit. F.A and Adaramola M.O. (2011) Effect of Collaborative Classroom on Nigerian Students with dyscalculia performance in mathematics. An online journal of education.http://www.academia.edu

[19]. Ugwu.A.N. and Etiubon, R.U.(2011): Changing STM. curriculum for the information age: Implications for the teachers: Global Journal online; http://www.globaljournalseries.com. 